\title{
Fin De Siècle Female Writers: Representing the New Femininity in the New Woman's Short Stories
}

\section{YüzyıI Sonu Kadın Yazarları: Yeni Kadının Kısa Öykülerinde Yeni Kadınsallığın Temsili}

\author{
Enes Kavak \\ Gaziantep University
}

\begin{abstract}
The New Woman as a radical female figure and a controversial literary construct appeared in the works of fin-desiècle feminist authors in Britain. Short story was a suitable form for the New Woman to represent new femininity and express her opinions both in content and form. Her short stories portrayed a large body of female characters that could be identified with her smoking habits, masculine outfits and manners as well as strong feminist arguments. This paper attempts to identify what the possible meanings are engendered by the constructions of new femininity and her unconventional personalities that promote women's artistic creativity, performance of pseudo-masculinity as well as free act and speech for gender equality. The stories examined in this paper have been selected from Elaine Showalter's book entitled Daughters of Decadence: Women Writers of the Fin-de-Siècle, which includes a representative selection of short stories written by female writers. In this selection, it has also been important to determine in what ways the collection of short stories in this edition offered a common discourse about these women's stance over the issue of female liberties and their personal struggle in their private lives.
\end{abstract}

Keywords: The New Woman, new femininity, fin de siècle, short stories

\section{Özet}

Radikal bir kadın figürü ve tartışmalı bir edebi karakter olarak Yeni Kadın, ondokuzuncu yüzyıl sonunda İngiltere'de feminist kadınlar tarafından yazılmış eserlerde ortaya çıktı. Kısa hikaye, yeni kadınlığın temsili ve görüşlerini ifade etmesi için hem içerik hem de biçim açısından uygun bir türdü. Yeni Kadır'ın öyküleri, sigara içme alışkanlıkları, erkeksi duruşları ve davranışları ile güçlü feminist argümanlarıyla özdeşleşmiş çok sayıda karakteri canlandırdı. Bu makale, Yeni Kadının yaratılmasında sanatsal yaratıclık, sözde erkeksiliğin sergilenmesi, kadın hakları hakkındaki ifade and davranış özgürlüğü ile ortaya çıkan anlamları tanımlamaya çalışmaktadır. Bu yazıda incelenen eserler, kadınlar tarafından yazıımış kısa öykülerin temsili bir derlemesini içeren, Elaine Showalter'un Daughters of Decadence: Women Writers of the Fin-de-Siècle başlıklı kitabından seçilmiştir. Bu seçimde, kitapta bulunan kısa hikaye tercihilerinin, kadın özgürlükleri ve kişisel mücadeleleri konusunda, hangi yönlerden ortak bir söylem yaratıldı̆̆ını belirlemek önemli olmuştur.

Anahtar Kelimeler: Yeni Kadın, yeni kadınsalık, yüzyıl sonu, kısa öyküler

\section{Introduction}

The New Woman, who used literature as a potent medium for self-expression and selfrepresentation, is in essence a radical figure defying gender inequality, women's negligible role in public life and patriarchal politics as well as masculine scientific discourse on female sexuality in the latenineteenth century Britain. Female characters constructed in the New Woman stories defy labels, but in many respects, their bold and eccentric personalities were hailed as the embodiment of the progressive feminism and they embody an antithesis to the docile and soulless female characters burdened literary works of the Victorian age.

The term, the New Woman, describes remarkably modern, artistically avant-garde and impudently eccentric women for their age, who were single in many cases, and championed their liberties by means of their outfits, manners and sentiments about womanhood and sexuality. As an immediate reaction, these women were not only branded deviant, but also a menace to the society in the published media at the turn of the twentieth century, especially in the popular periodicals and dailies such as Punch and The Times. To better illustrate, in a Punch caricature published in 1905, four women were portrayed playing cards around a table and discussing one of their friend's fiancé's reaction against her gambling and smoking in a bewildered and disapproving manner. They carry on playing cards while 
critiquing and being shocked at people's antagonistic views on women's gambling in general. ("Primum Vivere, Deine Philosophar: First one must live, then one may philosophize", 1905). This was just one of the examples of how the mainstream media created contemptuous caricatures and condemned the lifestyles and personalities of these women and their presence in the public life. As Ann Heilmann puts it, "the New Woman became a battleground for contesting viewpoints" (p. 23). Namely, her identity became susceptible to numerous attempts of distortion and deconstruction.

It is crucial to understand the peculiarities of English fin-de siècle in order to appreciate the exceptionality of the New Woman characters. It is relatively problematic to define and categorise the last decade of nineteenth century (which is also called Decadence or fin-de siècle) when the New Man and the New Woman emerged as literary phenomena. It would be useful to remember Showalter's words at this point: "history warns that after the revolution comes the terror and decadence" (p. 20) to realise that this period was a time of confusion and questioning of moral and cultural values emerged in the aftermath of the industrial revolution in the nineteenth century. It was also a time of subversive ideas and experimental efforts in art as a reaction to the conservatism prevailed in the previous decades. The period simply featured a mix of misperception, transformation and avant-gardism, which again defy precise definitions and classifications. As Lionel Johnson defined in his The Century Guild Hobby Horse, the Decadence was "an age of afterthought, of reflection" as a literary and historical period (Johnson, 1891, p. 6).

In such a context, short story proved to be the genre that could provide the New Woman writer with a suitable form to express herself. Most basically, it did not need to carry the essential literary elements of longer genres such as plot, characterisation or a dénouement. The reason why a great many women writers at fin-de-siècle preferred short stories was simply to transgress the restrictions of literary production. Concerning their rejection of conventionality, neither realism nor naturalism was of use any longer in their works; instead their works were equated with the literary movements of aestheticism and symbolism (Pykett, p. 2). Short stories were diverse in their themes, yet the New Woman, by and large, reinterpreted the issues such as sexual desire, motherhood, marriage, death and female emancipation in experimental, at times avant-garde way. A selection of short stories of the period would be useful to define the constructions and characteristics of femininity championed by the New Woman writers. Therefore, this paper aims to reveal in what ways the New Woman offer a common and unified discourse on female liberties and differs herself from the conventional through her examination of sexuality, womanhood and personal freedom within the realm of short stories.

\section{New Women in the Turn-of-the-century Short Stories}

Kate Chopin's story An Egyptian Cigarette, which was published in 1897, portrays a bold scene of a woman's dream-like fantasy, depicting her as smoking cigarette in solitude. The heroine's silent and passionate expression of sexuality is embodied in the act of smoking cigarette or opium with their soothing and inspiring effects. The cigarette, itself, is a symbol of the New Woman with its masculine and machoistic allusions. It highlights Chopin's examination of female passion, aiming to show how a woman can feel intensely passionate and sexually free in her fantasies. However, in the story, the cigarette and its smoke also make allusions to the unknown past of the heroine. It is gifted by "a species of fakir" and "it bears no label, no stamp-nothing to indicate its contents" (Chopin, An Egyptian Cigarette, 1993, p. 1). The fact that characters have neither names nor identities contributes to the sense of ambiguity and mystery about the New Woman's character. Smoking suggests a sense of inspiration and excitement, and the narration is eroticised in a way that every inhalation takes the woman to the exotic world of "the Orient" (p. 1). The moment is described as if it took place in a mystical setting:

A subtle, disturbing current passed through my whole body and went to my head like the fumes of disturbing wine. I took another deep inhalation of the cigarette. The grey-green smoke arose in a small puffy column that spread and broadened, that seemed to fill the room. I could see the maple leaves dimly, as if they were veiled in a shimmer of moonlight. (Chopin, p. 2)

The representation of a woman in a scene of smoking with a sexualised undertone is in entire opposition to the Victorian belief in "women's passionlessness" and absence of female sexual desires (Showalter, 1990, p. 45). Proving her divergent character, the woman wishes to go away from "the 
chatter of the women that reach[s] her faintly" (Chopin, p. 2). In a short period of seclusion, the heroine feels like travelling to an exotic country. Yet, it does not take long that her sexual passion turns into disillusionment with a memory of a man who disdains her:

Oh! I am tired of fetters, and kisses, and you, I am going away. You will never see me again. I am going beyond, where the monster stones are rising heaven ward in a moment for the unborn ages. Oh! I am tired. You will see me no more.

(Chopin, p. 3)

The man's despotic remarks result in pain in the woman's body and she experiences "the depths of human despair" (Chopin, p. 4), reminding the reader that women yearned for independence regarding her sexuality and self-expression. The story exemplifies the New Woman's argument for free expression of female passion and desire which were fully censored by the Victorian male writers. During the century, it was a common tendency for writers to emphasize women's chastity in their works. In Chopin's story, on the other hand, passion is presented as a natural instinct of femininity, so even a simple act of smoking can allude to an expression of liberated sexuality. Every inhalation comes with a different feeling of joy and relaxation and the moment she smokes is given with exotic references. Paradoxically, however, the end of the story does not portray a sense of satisfaction or sorrow, keeping the reader curious about the woman's feelings and contributes to the air of mystery, successfully attained through symbolism and elusive tone of the narrator.

The portrayal of female sexuality takes a new form in Victoria Cross' Theodora: a Fragment, which was published in the Yellow Book in 1895. The story appears to condemn artistic representation of physicality, by questioning the Decadent artists' dramatization of female characters as the sexual object of their art. Two of most famed and fascinating literary characters featured in fin-de-siècle British literature were the Decadent and The New Woman. Despite the fact that the Decadent attracted most of public attention, the New Woman campaigned against the double standard of patriarchy and predetermined gender roles, and diverged from the norms.

Victoria Cross does not offer us a conventional story, but she simply depicts a brief meeting of a man and woman: a short story, a fragment, of impressions from the perspective of a male narrator. The marks of imagination originate from the form and burgeon in the author's disproval of male view on female attractiveness and aesthetic beauty. The narrator does not conceal his appreciation of feminine qualities, describing Theodora as though she were a possession of an artist or basically, a possessor her potential husband. Clair Hanson notes a common characteristics that many New Woman stories of the period

are structured around the encounter between a male narrator or protagonist and a woman who is presented in iconic terms, frequently with explicitly painterly references. (Hanson, p. 136)

In this light, a lengthy account of the artist's description of Theodora as his art piece offers us clues:

Unconsciously a certainty of possession of Theodora to-day, to-morrow, or next year, filled me for the moment as completely as if I had just made her my wife. The instinct that demanded her was immediately answered by a mechanical process of the brain, not with doubt or fear, but simple confidence. "This is a pleasant and delightful object to you- as others have been. Later it will be a source of enjoyment to you -as others have been." And the lulling of this painful instinct is what we know as pleasure. [...] If the object is worthy and lovely in any sense, we should be ready to love it as being such, for itself, as moralists preach to us of Virtue, as Theologians preach to us of the Deity. To love or at least to strive to love an object for the object's sake, and not our own sake, to love it in its relation to its pleasure, is to feel the only love which is worthy of offering to a fellow human being, the one which elevates - and the only one - both giver and receiver. (Cross, Theodora, 1990, p. 16)

This unmistakably masculine soliloquy of the narrator reminds two principally differing and irreconcilable views: the view that sees women as domestic servants and late-nineteenth century avantgarde male painters' or artists' wish to degrade woman to the level of a simple object featuring in their arts. The former view considers women to be passive, domestic and vulnerable creatures whose duty is to raise children, carry out errands and live as devoted wives, concealing her longings or bodily passion. As Marianne Berger Woods puts it, "Victorian society regarded women as incapable of taking 
care of themselves, assuming the protection of men was necessary" (p. 6). The female refusal of this oppression brought about medicine and science's warnings that ambition to female self-development "would lead to sickness, freakishness, sterility and racial degeneration" (Showalter, 1990, p. 39). The fact that the only way for a woman to sustain a decent life in the era was via mercenary marriage with a man to support her is recurrently echoed here. Theodora is showed in a "risk of losing her money" and "if she married a poor man, it would be rather a severe drop for her" (p. 9). However, Theodora challenges idea of the women's living in a state of dependency.

Nevertheless, the latter view degrades woman as a lifeless object whose function can be no more than an ornament to be admired or the subject of art to be reconstructed or imitated. It is worth noting that this "commo-dification and fetishization of women [at fin-de-siècle] has been explored by feminist scholars" repeatedly (Hanson, p. 136), which aroused their disdain and criticism against male intellectual and artistic mind. Ostensibly, in this story a New Woman is formulated to break the barriers of the male artists' imagination, and Theodora notes her fondness on personal liberty, by declaring that she prefers sleeping on the floor instead of a couch due to its physical boundaries. This preference is not only a matter of a bed choice, but it reveals her choices in life as a whole. The narrator confirms this interpreting the woman's silent act:

I lay myself voluntarily on the floor, knowing it thoroughly as a trifle low, but undeceptive and favourable to the condition of sleep which will probably arise, and suitable to my requirements of ease and space. I avoid the restricted and uncertain couch, recognising that if I fall to sleep on that raised level, and the desire stretch myself should come, I shall awake with pain and shock to feel the ground, and see above me the couch from which I fell - do you see? [...] her eyes told me that these ethics of the couch and floor covered the ethics of life. (Theodora, p. 16)

Theodora's ethical values define those of the New Woman. For her, the confines of male imagination are insufficient and she should flee from her physical and artistic captivity. Cross places her heroine in a way in which she counteracts the male "narrator's delighted sense of ownership" (Theodora, p. 24) and the finale reinforces her desire for autonomy. She leaves the house, which signifies once more that "women's sexual narratives are unfinished" (Showalter, 1993, p. xi) and deserves a medium of articulation and proclamation. It is worth noting that Cross's strategy and argument are different from that of Kate Chopin, simply because Theodora's main focus seems more to despise the intellectual arrogance of masculinity about issues such as female freedom and her degraded value as a sexualised object. Nonetheless, Cross's preference for a form of disdain rather than a more defiant and marginal portrayal of a fully emancipated femininity creates a dilemma and this strategy seems to fail to examine the issue of women's self-determination and the significance of the New Woman as an intellectual figure, a rival to the Decadent artist.

Another examination of the relationship between two sexes and the institution of marriage are presented in Olive Schreiner's story The Buddhist Priest's Wife (1892). It is one of the most disputed stories of her time, which might be considered a candid dialogue between the New Woman and the New Man. The woman invites a politician friend to her small flat, whom she is covertly infatuated with, just before setting out for a journey to India. Despite her affection for him, she is aware of fact that they are not at the same page about her role as a single woman. The man fails to appreciate her needs and her feelings about a relationship. This results in his contemptuously mocking of her choices.

But really what have you been doing with yourself all this time? You've entirely disappeared from civilised life. When I was down at the Grahams' in the spring, they said you were coming down there, and then at the last moment cried off. We were all quite disappointed. What is taking you to India now? Going to preach the doctrine of social and intellectual equality to the Hindu women and incite them to revolt Marry some old Buddhist Priest, build a little cottage on the top of the Himalayas and live there, discuss philosophy and meditate? I believe that's what you'd like. I really shouldn't wonder if I heard you'd done it! (p. 86)

The woman reacts to this angrily by describing the suitable woman for the man: "she must second you in a thoroughly rational manner. She must have the same aims and tastes that you have" (p. 91). Marriage, for Schreiner, stands for the feminine subservience, which is totally conflicting with the New Woman's enlightened character. In one of her letters, Schreiner argues that "it is not against 
men we have to fight but against ourselves within ourselves" (Schreiner, p. 145). Being aware of intellectual potential of woman, she underpins the liberation of female intellect as the basis of her ultimate goal of autonomy. Similarly in her story Life's Gifts, she personifies "Life", who asks a sleeping woman to make a choice between "Freedom" and "Love". As a reply, she chooses her freedom; so appreciating her choice, Life tells her "the day will come when I shall return." (p. 317), assuring that both would have gone in her life if she preferred the other.

The man explains that the truth beneath his idea of marriage "is not love, passion, he wants; it's a home; it's a wife and children" (p. 90). The idea from which the New Woman writing is originated purely materializes in Schreiner's heroine's statements. As she says "for a woman, marriage is much more serious than for a man" (p. 90), she actually criticises what men look for in a marriage. That's why, the writer challenges "bourgeois woman's career of marriage and motherhood" as idleness (Ardis, p. 1). It is not a union based on an egalitarian ground, yet it is a product of bourgeois ideals, confining women into the private sphere, depriving them from formal education, and leaving her alone outside the public and social life. The author thus recognises the massive gap between the New Man's and the New Woman's views on marriage.

A final theme examined in the New Woman's short stories is the theme of death as an escape as well as a freeing act in the story $A$ White Night (1903) by Charlotte Mew. A journey made by a male narrator, her newly-wed sister and brother-in-law to one of the unknown town in Spain is narrated in the tone of a quest novel. The place is described as "resolutely lifeless" (p. 123) and it invites them through "a little door, unlocked" (p. 123). As if travelling in an adventure land, characters find themselves in a church. At this point, the story implicitly refers to the novels of the quest romance writers of fin-de-siecle which, as a common subject, present its protagonist's travel to an unknown country, in which femininity is associated with helplessness and vulnerability. But, the crisis reveals at the point when these characters have to watch a woman's sacrifice secretly. The church scene unveils what Mew attempts to say:

And then one lost the sense of their diversity in their resemblance; the similarity persisted and persisted till the row of faces seemed to merge into one face - the face of the nothing human - of a system, of a rule. It framed the woman's and one felt the forces of it: she wasn't in the hands of men. (p. 129)

The notion of death for the female victim does not denote what it has meant to male characters in the story. The heroine dies not for the sake of her lover or society but herself. Death is described inevitable, but her courage in the wake of sacrifice appears to free herself from fear and the graveness of the situation. The writer degenerates the theme of death, carrying it to a greater and more philosophical context instead of just condemning the male quest fiction writer's narrow depiction of female participation and their overemphasis on so-called masculine values such as courage and fidelity to male bond. In $A$ White Night, the woman is not frightened of her end; instead she seems victorious as the hero of male narratives does when he escapes from it. The death in the story is a proud act finishing the chaos and provoking the reader to question the popularity of selfless and vulnerable femininity in the fin-de-siècle novels.

A clear criticism comes forth when the narrator puts himself into a position in which he safely watches the dramatic scene of the burial as a religious ritual and an artistic scenery. Thus, indeed $A$ White Night features a haunting narrative. The scene describes the group hiding in the secure distance and witness the whole proceeding of the ancient ritual performed by the monks, burying a woman alive. The woman is sacrificed in an unknown and secluded part of Spanish town. The group watching the live burial are overwhelmed by the words of the male narrator, Cameron. He seemingly criticises the woman's passive acceptance of her end. He instinctively does nothing to help the victim and waits to see her death, even blaming her for lifeless attitude: "it was she who had the key to what I might have done but didn't do" (p. 133). Cameron's words distance himself from any intimacy or understanding of the solemnity and graveness of the night-long criminal act. Instead, he describes the incident with a phrase such as "proud surrender" to describe the woman not as a victim but more of a willing surrender to the faith. Similarly, the monks are described as a group rather than individuals, making the criminal act a portrayal of the decision made by general consensus. Thus, humanly qualities disappear and a sense of crowd or a communal body is shaped, and legitimacy of the act seems to be intended. There are neither explanations made nor motives questioned in the story. Instead, the narrator paints an 
obscure and evocative scene with an allusion to the symbolical silencing of woman by an oppressive society.

\section{Conclusion}

The New Woman, in short stories, seeks to redefine and degenerate the representation of woman, seeking to instigate a revolt against the literary presentation of femininity in the Victorian society. Realising that established forms and literary movements such as realism or naturalism would not serve to her ends, she instead integrates symbolism and avant-gardism in short stories as appropriate means of experimenting with form and content to create her unique form of expression. In her stories, she simply intends to reconstruct and re-present woman's identity problem, by freeing her heroine from what surrounding society appeals her to be. In doing so, she liberately discusses genderfocused issues such as feminine passion, sexuality, marriage and freedom. A possible conclusion shall be drawn from those stories by noting Sally Ledger's remarks:

If there was any common ground between the women who register most resonantly as New Woman Writers, it was an insistence on the need to explore, redefine and celebrate women's sexuality, and a need to show how artificially women's sexual, [intellectual and emotional] nature had been constructed (and contaminated) by a male dominated society. (Shaw and Randolph, p. 9)

The New Woman is ideologically committed to rejuvenate the idea of the female genius and defy the male control over literary and artistic sphere of the late nineteenth century. She marginalizes herself and her literary creation, fashioning her own characters. Using allusions to masculine attributes such as smoking can be seen as a consequence of these reconstructive attempts.

It is certain that the New Woman stories are not completely unified or cohesive. They differ in their themes, use of symbolism and their way of portraying femininity. Her short stories condemn the age's view of woman as an artistic object in the eyes of intellectual men. These writers clearly disapprove the limited representation of women in the male art. In short stories, heroines are exhausted of male mind's limitations. Theodora's description of her ethics on her sleeping place signifies her desire to get rid of these boundaries. Moreover, the New Woman purposefully attacks the patriarchal marriage. While the New Woman writers consider marriage to be mental submission, male authors constructed it as an essential element of bourgeois society. Likewise, death is a theme to have been re-textualized in the woman stories. To her, femininity should be freed from imperial ambitions of masculine texts. Dying females in these works are vulnerable, sentimental and stereotypical, but in short stories by turn-ofthe-century women, the heroine, despite being a victim, is proud, unyielding and strong-minded. Therefore, these stories constitute an attack to the Decadent writers and the Victorian imperialism in romance fiction even though they are divergent and varying in content and symbolic in form.

\section{Bibliography}

Ardis, Ann L. (1990). New Women, New Novels: Feminism and Early Modernism. London: Rutgers University Press.

Chopin, K. (1993). An Egyptian Cigarette. In Showalter, E. (Ed.). Daughters of Decadence: Women Writers of the Fin-de-Siecle. (pp. 1-5). London: Virago Press.

Cross, V. (1993). Theodora: a Fragment. In Showalter, E. (Ed.). Daughters of Decadence: Women Writers of the Fin-de-Siecle. (pp. 6-37). London: Virago Press.

Fletcher, I. (Ed.). (1979). Decadence and the 1890s. London: Edward Arnold Publishers.

Gardiner, J. (Ed.). (1993). The New Woman. London: Collins and Brown Publishing.

Hanson, C. (1996). The Lifted Veil: Women and Short Stories in the 1880s and 1890s. The Year Book of English Studies. 31, pp. 135-142.

Heilmann, A. (2000). New Woman Fiction: Women Writing First-Wave Feminism. London: Macmillan Press.

Mew, C. A White Night (1903). In Showalter, E. (Ed.). Daughters of Decadence: Women Writers of the Fin-de-Siecle. (pp. 118-138). London: Virago Press.

"Primum Vivere, Deine Philosophar: First one must live, then one may philosophize". Punch. 1905.

Pykett, L. (Ed.). (1996). Reading Fin de Siècle Fictions. Essex: Longman Addison Wesley. 
Schreiner, O. (1988). Letter to Mary Roberts (1889). Rive R. (Ed.), Olive Schreiner: Letters. London: Oxford University Press.

Shaw, M. and Randolph, L. (2007). New Woman Writers of the Late Nineteenth Century. Devon: Northcote.

Showalter, E. (Ed.). (1993). Daughters of Decadence: Women Writers of the Fin-de-Siècle. London: Virago Press.

Showalter, E. (1990). Sexual Anarchy: Gender and Culture at the Fin de Siècle. London: Virago Press. Woods, Marianne B. (2009). The New Woman in Print and Pictures: An Annotated Bibliography. London: McFarland \& Company Publishers. 